\title{
Evaluation of Ventricular Repolarisation Features with Novel Electrocardiographic Parameters in Patients with Severe Periodontitis
}

\section{Şiddetli Periodontitisli Hastalarda Ventriküler Repolarizasyon Özelliklerinin Yeni Elektrokardiyografik Parametrelerle Değerlendirilmesi}

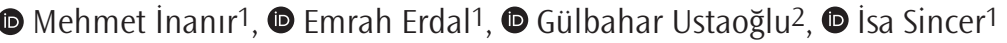 \\ ${ }^{1}$ Bolu Abant İzzet Baysal University Faculty of Medicine, Department of Cardiology, Bolu, Turkey \\ 2Bolu Abant İzzet Baysal University Faculty of Dentistry, Department of Periodontology, Bolu, Turkey
}

\begin{abstract}
Introduction: Ventricular arrhythmic predictors in severe periodontitis may be linked with cardiovascular events and the sudden death risk. In this study, we evaluated certain electrocardiographic (ECG) ventricular arrhythmic predictors in patients with severe periodontitis.

Methods: ECG parameters of 72 patients diagnosed with severe periodontitis, which are indicative of ventricular arrhythmia, were examined, and these parameters were compared with the control group.

Results: Compared to the control group, QT interval (QT) $(p=0.014)$, corrected QT $(\mathrm{QTc})(p<0.001)$, QT dispersion $(\mathrm{QTd})$ $(p<0.001)$, QTdc $p<0.001)$, JT interval $(p=0.012)$, JTc interval $(p<0.001)$, T peak and end interval (Tp-e) $(p<0.001)$, Tp-e/ QT ratio $(p<0.001)$, Tp-e/QTc ratio $(p<0.001)$, Tp-e/JT ratio $(p<0.001)$ and Tp-e/JTc ratio $(<0.001)$ were found to be higher in patients with severe periodontitis.

Conclusion: Our study showed that arrhythmic ECG markers were significantly prolonged in patients with severe periodontitis. In future extensive prospective studies, we think that these arrhythmic predictors should be evaluated to predict malignant arrhythmias.
\end{abstract}

Keywords: Arrhythmia, electrocardiography, periodontitis, JTc interval, Tp-e/QTc ratio

\section{öZ}

Amaç: Șiddetli periodontitiste ventriküler aritmik prediktörler kardiyovasküler olaylar ve ani ölüm riski ile ilişkili olabilir. Bu çalışmada şiddetli periodontitisli hastalarda bazı elektrokardiyografik (EKG) ventriküler aritmik prediktörler değerlendirilmiştir.

Yöntemler: Şiddetli periodontitis tanısı alan 72 hastanın, ventriküler aritminin göstergesi olan EKG parametreleri incelendi ve bu parametreler kontrol grubuyla karșılaștırıldı.

Bulgular: Kontrol grubu ile karșılaștırıldığında, şiddetli periodontitisli hastalarda QT aralığı $(p=0,014)$, düzeltilmiş QT aralığı (QTc) $(p<0,001)$, QT dağılım aralığı (QTd) $(p<0,001)$, QTdc aralığı $p<0,001)$, JT aralığı $(p=0,012)$, JTc aralığı $(p<0,001), T$ tepe ve bitiş aralığı (Tp-e) $(p<0,001)$, Tp-e/QT oranı $(p<0,001)$, Tp-e/QTc oranı $(p<0,001)$, Tp-e/JT oranı $(p<0,001)$ ve Tp-e/JTc oranı $(<0,001)$ daha yüksek bulundu.

Sonuç: Araştırmamız, şiddetli periodontitisli hastalarda aritmik EKG belirteçlerin anlamlı șekilde uzadığını göstermiștir. Gelecekteki kapsamlı prospektif çalıșmalarda, bu aritmik belirleyicilerin malign aritmileri öngörmek için değerlendirileceğini düşünüyoruz.

Anahtar Kelimeler: Aritmi, elektrokardiyografi, periodontitis, JTc aralığı, Tp-e/QTc oranı

\section{Introduction}

Periodontitis is a chronic inflammatory periodontal disease that gradually destroys the supporting structures of the teeth, affecting approximately $50 \%$ of the adult population (1). The harmful influences of periodontitis are not only restricted to the oral cavity, but it also affects general health (2). Classification of periodontitis is based on stages defined by the severity, complexity, and distribution (Table 1).
There is consistent and potent epidemiological evidence that periodontitis increases the risk of cardiovascular disease [(CVD); for example, atherosclerosis with different mechanisms] (5).

Electrical changes in the heart throughout ventricular repolarisation can cause fatal rhythm disturbances (6). Myocardial depolarisation and repolarisation have been assessed using various methods. QT interval (QT), QT dispersion (QTd) and corrected QT (QTc) have been linked with ventricular arrhythmic conditions and sudden death (7).
Address for Correspondence/Yazıșma Adresi: Mehmet İnanır MD, Bolu Abant İzzet Baysal University Faculty of Medicine, Department of Cardiology, Bolu, Turkey

Phone: +90 5437941435 E-mail: mdmehmetinanir@yahoo.com ORCID ID: orcid.org/0000-0003-1784-3584

Cite this article as/Atıf: İnanır M, Erdal E, Ustaoğlu G, Sincer I. Evaluation of Ventricular Repolarisation Features with Novel Electrocardiographic Parameters in Patients with Severe Periodontitis. İstanbul Med J 2020; 21 (5): 366-9.
Received/Geliș Tarihi: 26.04.2020 Accepted/Kabul Tarihi: 22.07 .2020

(c) Copyright 2020 by the University of Health Sciences Turkey, Istanbul Training and Research Hospital/Istanbul Medical Journal published by Galenos Publishing House.

(C) Telif Hakkı 2020 Sağlık Bilimleri Üniversitesi Istanbul Ĕgitim ve Araştırma Hastanesi/Istanbul Tıp Dergisi, Galenos Yayınevi tarafından basılmıștır. 
In recent years, JT, JTc, T peak and end interval (Tp-e) and Tp-e/QT and Tp-e/QTc proportions have also shown to be different parameters indicating fatal ventricular arrhythmias (8).

In this study, we aimed to explore the influence of severe periodontitis on cardiac ventricular arrhythmic abnormalities.

\section{Methods}

\section{Study Population}

Electrocardiogram (ECG) recordings of 72 patients with periodontitis who were received in the University of Bolu Abant İzzet Baysal Department of Periodontology between July 2018 and December 2018 were crosssectionally analysed and compared with controls. The study was conducted after obtaining ethical approval from the Bolu Abant Izzet Baysal University Ethics Committee (decision number: 2019/264, date: 21/11/2019).

The study was conducted in compliance with the ethical principles according to the Declaration of Helsinki.

Patients were diagnosed as having periodontitis or were declared to be periodontally healthy based on the criteria proposed by the International Workshop for the Classification of Periodontal Diseases and Conditions in 2017 (1). All patients agreed to participate in the study and gave their written informed consent.

\section{Exclusion Criteria}

Participants with a history of diabetes, smoking, hypertension, hyperlipidaemia, structural heart disease, atherosclerotic CVDs (coronary artery disease, etc), ejection fraction $<50 \%$, electrolyte imbalances, liver failure, thyroid disorders, renal failure, malignancies, chronic lung disease, or any other systemic illness were excluded. Besides, patients over 45 years old were excluded because of the reduced risk of an arrhythmic event with ageing. Participants with a history of ventricular arrhythmias, atrial fibrillation (AF), and those having left-axis deviation, ST-segment depression, and hypertrophic findings on ECG were also excluded, because of the possible influences of these ECG differences on the computed ECG parameters.

Table 1. The 2017 workshop on the classification of periodontal and peri-implant diseases and conditions (1)

Stages: Based on the severity (3) and complexity of management (4)

Stage I Initial periodontitis

Stage II Moderate periodontitis

Stage III Severe periodontitis with potential for additional tooth loss

Stage IV Severe periodontitis with potential for loss of the dentition

Table 2. General characteristics of the study groups

\begin{tabular}{|l|l|}
\hline Baseline characteristics & $\begin{array}{l}\text { Severe periodontitis } \\
\text { Mean } \pm \text { SD }(\mathbf{n}=72)\end{array}$ \\
\hline Age (years) & $35.4 \pm 6.7$ \\
\hline Male/female & $56 / 16$ \\
\hline BMI & $25.5 \pm 3.4$
\end{tabular}

BMI: Body mass index, SD: standard deviation

\section{Electrocardiography}

The 12-lead ECG was recorded with the Nihon Kohen Cardiofax ECG1950 VET device. Two cardiologists, blinded to the data, performed the ECG measurements and calculations manually with the TorQ $150 \mathrm{~mm}$ digital caliper LCD device. QT interval was measured, beginning from the initiation of the QRS duration to the end of the T wave. JT interval was measured from the end of the QRS complex to the end of the T wave. QTd was defined as being the difference between the maximum and minimum QT intervals measured at different leads. The Tp-e range is the range from the peak of the T wave to the end of the T wave. QTC, QTdc and JTc were calculated using the Bazett's formula (QTc= QT/ $/ R R)$ (9). Besides, the rates of these intervals calculated, the differences between intra-observer and inter-observer measurements were below 5 percent.

\section{Statistical Analysis}

Analyses were conducted using the SPSS 21.0 Statistical Package Program for Windows (SPSS Inc, Chicago, Illinois, USA). Mean \pm standard deviation was used for quantitative variables, and numbers and percentages were used to express qualitative variables. In independent groups, the chisquare test was used for qualitative variables, and the Student t-test was used for quantitative variables. A p value less than 0.05 was considered statistically significant.

\section{Results}

The baseline characteristics of the study and control groups were similar (Table 2).

Compared to the control group, QT interval (376.7 \pm 21.4 vs. $362.3 \pm 27.0$ ms, $p=0.014)$, QTc $(404.4 \pm 24.2$ vs $381.0 \pm 16.7 \mathrm{~ms}, \mathrm{p}<0.001)$, QTd (26.5 \pm 11.2 vs. $18.0 \pm 5.9 \mathrm{~ms}, \mathrm{p}<0.001)$, QTdc $(28.6 \pm 12.0$ vs $18.9 \pm 5.7$ $\mathrm{ms}, \mathrm{p}<0.001)$, JT interval $(293.0 \pm 39.2$ vs $272.4 \pm 27.2 \mathrm{~ms}, \mathrm{p}=0.012)$, JTc interval (312.9 \pm 22.6 vs $286.1 \pm 18.3 \mathrm{~ms}, p<0.001)$, Tp-e interval (106.9 \pm 12.0 vs. $73.6 \pm 7.4 \mathrm{~ms}, \mathrm{p}<0.001)$, Tp-e/QT ratio $(0.28 \pm 0.03$ vs $0.20 \pm 0.03, p<0.001)$, Tp-e/QTc ratio $(0.27 \pm 0.04$ vs $0.19 \pm 0.02, p<0.001)$, $\mathrm{Tp}$-e/JT ratio $(0.37 \pm 0.05$ vs $0.27 \pm 0.03, \mathrm{p}<0.001)$ and $\mathrm{Tp}$-e/JTc ratio $(0.34 \pm 0.04$ vs $0.26 \pm 0.03, p<0.001)$, were found to be higher in patients with severe periodontitis (Table 3), (Figure 1).

\section{Discussion}

In our study, we showed that periodontitis is significantly linked with arrhythmic predictors. To the best of our knowledge, there is no other study investigating cardiac ventricular markers in periodontitis patients.

Periodontitis is an increasing epidemic health problem that has been thought to be a risk factor for myocardial infarction (10). Although

\begin{tabular}{l|l|}
$\begin{array}{l}\text { Control group } \\
\text { Mean } \pm \text { SD }(\mathbf{n}=72)\end{array}$ & $p$ \\
\hline $33.5 \pm 6.4$ & 0.222 \\
\hline $46 / 26$ & 0.200 \\
\hline $25.3 \pm 3.2$ & 0.842 \\
\hline
\end{tabular}


Table 3. Electrocardiographic findings of the study population

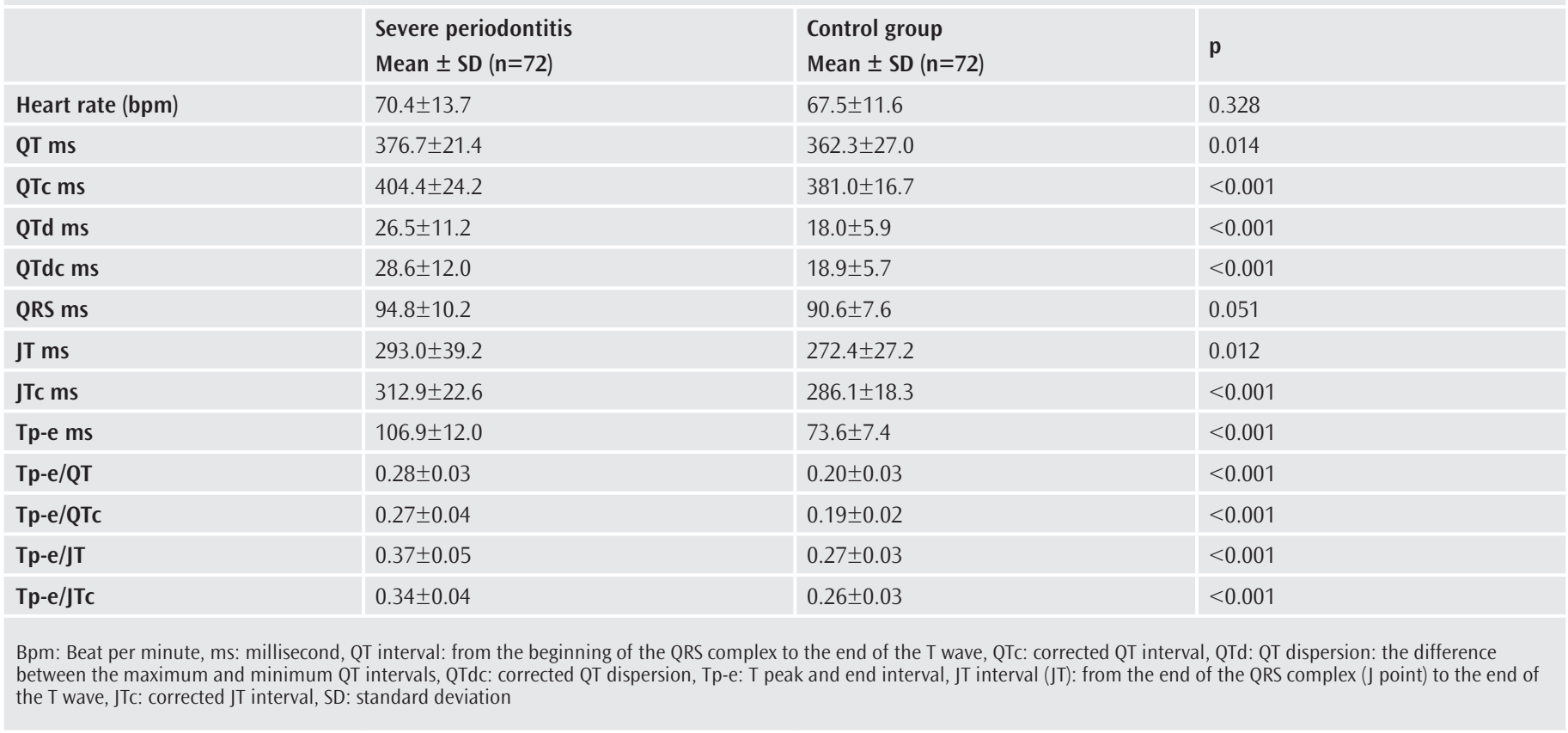

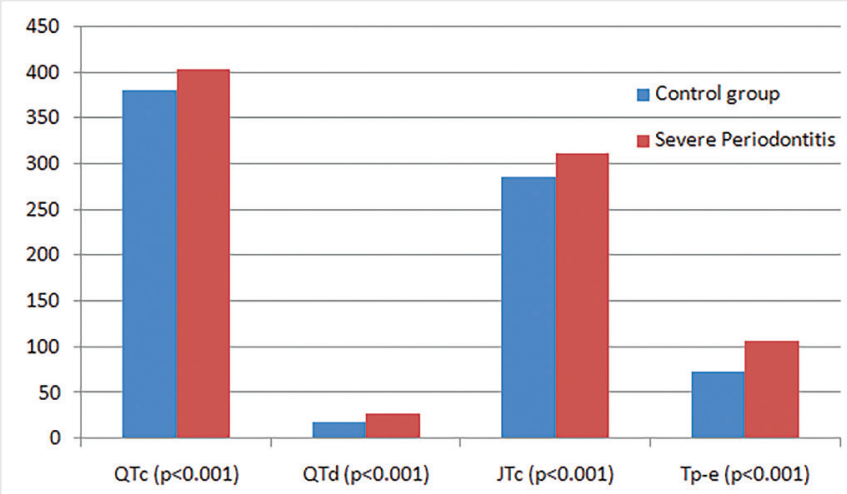

Figure 1. QTC, QTd, JTc and Tp-e distributions of the control and severe periodontitis groups

QTc: Corrected QT interval, QTd: difference between the maximum and minimum QT intervals, JTc: corrected JT interval, Tp-e: T peak and end interval

patients with periodontitis are successfully treated, life-long supportive care is recommended for these patients (11). The systematic inflammatory response leads to endothelial dysfunction, and endothelial dysfunction also contributes to CVDs (12), especially electrocardiographic anomalies that are sensitive predictors of lethal coronary heart disease (CHD), and are significantly linked to subsequent death from CHD (13). In the literature, Shimazaki et al. (14) showed a relationship between periodontitis and ECG abnormalities and CVD. Additionally, Im et al. (15) concluded that AF patients with periodontitis, as representative of chronic inflammation, were more prone to have arrhythmic events such as AF, atrial flutter, atrial tachycardia, and any other events than those without periodontitis.

Studies have shown that the QT, QTc, QTd, QTdc JT, JTc and Tp-e intervals are a risk predictor for arrhythmia and sudden death (7,8,16-18).
The QT is affected by the QRS duration (19). QTd has been declared as an indicator of ventricular arrhythmias (17). Also, an increase in QTd was found to be related to sudden death (18).

The JT interval is the portion of the QT that only shows repolarisation (20). The Tp-e range is a relatively new electrocardiographic parameter showing the entire repolarisation distribution $(21,22)$.

Besides, rates of Tp-e/QTc (23) and Tp-e/JTc (24) have also been found to be related to malignant ventricular arrhythmias.

Periodontitis has been suggested to cause CVDs in different ways. For whatever reason, our study showed that these patients were prone to malignant ventricular arrhythmias. In addition to conventional risk factors for CVDs, inflammation is also considered as being a probable risk factor for CVDs.

\section{Conclusion}

Our study showed that arrhythmic ECG markers significantly increased in patients with severe periodontitis.

In future extensive prospective studies, we think that these arrhythmic predictors should be evaluated to predict malignant arrhythmias.

Automatic methods are more recommended than manual measurements (25). Besides, the number of patients in this study may be comparatively small.

\section{Ethics}

Ethics Committee Approval: The study was conducted after obtaining ethical approval from the Bolu Abant İzzet Baysal University Ethics Committee (decision number: 2019/264, date: 21/11/2019).

Informed Consent: All patients agreed to participate in the study and gave their written informed consent. 
Peer-review: Externally and internally peer-reviewed.

Authorship Contributions: Surgical and Medical Practices - M.I., G.U., E.E., I.S.; Concept - M.I., E.E., G.U., I.S.; Design - M.I., E.E., G.U., I.S.; Data Collection or Processing - M.I.., E.E., G.U.; Analysis or Interpretation - M.I., E.E., I.S.; Literature Search - M.I., E.E., G.U.; Writing - M.I., G.U., E.E., I.S.

Conflict of Interest: No conflict of interest was declared by the authors.

Financial Disclosure: The authors declared that this study received no financial support.

\section{References}

1. Johnson L, Bhutani VK. The clinical syndrome of bilirubin-induced neurologic dysfunction. Semin Perinatol 2011; 35: 101-13.

2. Li X, Kolltveit KM, Tronstad L, Olsen I. Systemic diseases caused by oral infection. Clin Microbiol Rev 2000; 13: 547-58.

3. Armitage GC. Development of a classification system for periodontal diseases and conditions. Ann Periodontol 1999; 4: 1-6.

4. Lang NP, Bartold PM. Periodontal health. J Periodontol 2018; 89(Suppl 1): S9s16.

5. Suzuki JI, Sato H, Kaneko M, Yoshida A, Aoyama N, Akimoto S, et al. Periodontitis and myocardial hypertrophy. Hypertens Res 2017; 40: 324-8.

6. Monitillo F, Leone M, Rizzo C, Passantino A, lacoviello M. Ventricular repolarization measures for arrhythmic risk stratification. World J Cardiol 2016; 8: 57-73.

7. Chugh SS, Reinier K, Singh T, Uy-Evanado A, Socoteanu C, Peters D, et al. Determinants of prolonged QT interval and their contribution to sudden death risk in coronary artery disease: the Oregon Sudden Unexpected Death Study. Circulation 2009; 119: 663-70.

8. Antzelevitch C. T peak-Tend interval as an index of transmural dispersion of repolarization. Eur J Clin Invest 2001; 31: 555-7.

9. Bazett HC. An analysis of the time relations of electrocardiograms. Heart 1920; 7: 353-70.

10. Stassen FR, Vainas T, Bruggeman CA. Infection and atherosclerosis. An alternative view on an outdated hypothesis. Pharmacol Rep 2008; 60: 85-92.

11. Chapple ILC, Mealey BL, Van Dyke TE, Bartold PM, Dommisch H, Eickholz P, et al. Periodontal health and gingival diseases and conditions on an intact and a reduced periodontium: Consensus report of workgroup 1 of the 2017 World Workshop on the Classification of Periodontal and Peri-Implant Diseases and Conditions. J Clin Periodontol 2018; (89 Suppl 1): S74-S84.

12. Hansson GK. Inflammation, atherosclerosis, and coronary artery disease. $\mathrm{N}$ Engl J Med 2005; 352: 1685-95.
13. Knutsen R, Knutsen SF, Curb JD, Reed DM, Kautz JA, Yano K. The predictive value of resting electrocardiograms for 12-year incidence of coronary heart disease in the Honolulu Heart Program. J Clin Epidemiol 1988; 41: 293-302.

14. Shimazaki Y, Saito T, Kiyohara Y, Kato I, Kubo M, lida M, et al. Relationship between electrocardiographic abnormalities and periodontal disease: the Hisayama Study. J Periodontol 2004; 75: 791-7.

15. Im SI, Heo J, Kim BJ, Cho KI, Kim HS, Heo JH, et al. Impact of periodontitis as representative of chronic inflammation on long-term clinical outcomes in patients with atrial fibrillation. Open heart 2018; 5: e000708.

16. Moss AJ. Measurement of the QT interval and the risk associated with QTC interval prolongation: a review. Am J Cardio 1993; 72: 23b-5b.

17. Macfarlane PW. Measurement of QT dispersion. Heart 1998; 80: 421-3.

18. Zareba W, Moss AJ, le Cessie S. Dispersion of ventricular repolarization and arrhythmic cardiac death in coronary artery disease. Am J Cardiol 1994; 74 : 550-3.

19. Crow RS, Hannan PJ, Folsom AR. Prognostic significance of corrected QT and corrected JT interval for incident coronary heart disease in a general population sample stratified by presence or absence of wide QRS complex: the ARIC Study with 13 years of follow-up. Circulation 2003; 108: 1985-9.

20. Bihlmeyer NA, Brody JA, Smith AV, Warren HR, Lin H, Isaacs A, et al. ExomeChipWide Analysis of 95626 Individuals Identifies 10 Novel Loci Associated With QT and JT Intervals. Circ Genom Precis Med 2018; 11: e001758.

21. Antzelevitch C, Sicouri S, Di Diego JM, Burashnikov A, Viskin S, Shimizu W, et al. Does Tpeak-Tend provide an index of transmural dispersion of repolarization? Heart rhythm 2007; 4: 1114-6; author reply 1116-9.

22. Erikssen G, Liestol K, Gullestad L, Haugaa KH, Bendz B, Amlie JP. The terminal part of the QT interval (T peak to $\mathrm{T}$ end): a predictor of mortality after acute myocardial infarction. Ann Noninvasive Electrocardiol 2012; 17: 85-94.

23. Zhao X, Xie Z, Chu Y, Yang L, Xu W, Yang X, et al. Association between Tp-e/QT ratio and prognosis in patients undergoing primary percutaneous coronary intervention for ST-segment elevation myocardial infarction. Clin Cardiol 2012; 35: 559-64.

24. Alvarado-Serrano C, Ramos-Castro J, Pallas-Areny R. Novel indices of ventricular repolarization to screen post myocardial infarction patients. Comput Biol Med 2006; 36: 507-15.

25. Grasser EK, Ernst B, Thurnheer M, Schultes B. QT Interval Shortening After Bariatric Surgery Depends on the Applied Heart Rate Correction Equation. Obes Surg 2017; 27: 973-82. 